\title{
Analysis of Groundwater Quality for Clean Water Supply in Pasaran Island, Bandar Lampung City, Indonesia
}

\author{
Maryadi Budi Wiyono ${ }^{1,2^{*}}$, Tjahyo Nugroho Adji ${ }^{1}$, Langgeng Wahyu Santosa ${ }^{1}$ \\ ${ }^{1}$ Faculty of Geography, Universitas Gadjah Mada, Jl. Kaliurang, Sekip Utara, Bulaksumur, Sleman \\ 55281, Yogyakarta, Indonesia \\ ${ }^{2}$ Ministry of Religion in Tanggamus Regency, Kotaagung Timur, Kotaagung 35384, Lampung, \\ Indonesia \\ *) Corresponding author (e-mail: maryadibudiwiyono@gmail.com)
}

Received: 08 October 2020 / Accepted: 08 July 2021 / Published: 31 July 2021

\begin{abstract}
Pasaran is the only productive small island functioning as the anchovy and green clam production center in Bandar Lampung. Its water use has, however, increased since its designation as an economically fishery-based development area or minapolitan in 2012. This is due to the fact that groundwater resources in small island ecosystems surrounded by seawaters with a narrow diameter are easily affected by the insistence of seawater. Moreover, population pressure and land-use change are also feared to be affecting groundwater quality. Therefore, this research was conducted to analyze and evaluate groundwater resource quality in Pasaran Island using five wells on the entire island as sampling points selected based on census. The samples were tested for physical, chemical, and biological parameters in the laboratory and compared with water quality standards (Minister of Health's Regulation No. 32/2007). The results showed relatively low water quality because the samples contained up to $3900 \mu \mathrm{S} /$ $\mathrm{cm}$ salinity, $3771.9 \mathrm{mg} / 1$ chlorides, $31.7-141.52 \mathrm{mg} / 1$ nitrates, and $6.8-170 \mathrm{MPN} / 100 \mathrm{ml}$ total coliform which exceed the standards for drinking water. Meanwhile, wells 1,4 , and 5 were found to be safe for sanitation-hygiene purposes and well 1 was suitable for public baths even though they are not of drinking quality. This means the groundwater quality generally met Class II-water requirements for clean water supplies.
\end{abstract}

Keywords: Pasaran Island; water quality; groundwater

\section{Introduction}

A small island is defined as any piece of land surrounded by water with an area lesser than 10,000 km2 (Nunn, 1986). It has, however, been discovered that most of them are lesser than $200 \mathrm{~km} 2$ in size, and those narrower than $100 \mathrm{~km} 2$ or with a maximum width of $3 \mathrm{~km}$ are classified as "very small islands" (Falkland et al., 1991). Meanwhile, groundwater is usually extracted from small, thin, alluvial (or carbonate) aquifers along the coastline in many small islands (UNESCO-IHP and UNEP 2016) or appears as a thin freshwater lens floating above seawater on coral sands and limestone aquifers (White et al., 2004). However, most of the groundwater is primarily sourced from rainwater which seeps into the soil in line with a process called the hydrological cycle (Purnama, 2010). This process changes the quality of the water in the soil apart from its influence on the availability of water when the environment's recharge function is disturbed by the anomalies in climate conditions, geology or rocks, vegetation, human activities, and others (Sudarmadji et al., 2019).

The groundwater quality in small tropical islands is highly vulnerable due to the effect of its limited surface area, low elevation, separate location, climate change and population, and land-use change (Bailey et al., 2016). Meanwhile, Pasaran which is a small island in the tropics has different water resource-related problems with the water quality observed from 
the field to have changed due to sanitary issues, tidal inundations, and a thin lens of groundwater storage. Therefore, this research was conducted to analyze water quality for clean water supply towards providing appropriate considerations to ensure suitable groundwater utilization for the government and community of Pasaran Island.

Several studies have been conducted on groundwater quality, for example, Cahyadi (2015) examined the effect of seawater intrusion on groundwater quality in Pramuka Island using calcium, sodium, magnesium, chloride, bicarbonate, and total coliform as parameters through the ion comparison method. Kang and Jackson (2016) also studied the salinity and total dissolved solids while Schneider and Kruse (2005) assessed the natural and anthropogenic impacts on water quality in the Dog Island groundwater lens using the density groundwater flow models. Moreover, Anthonj et al. (2020) examined water inequalities in the Solomon Islands using a quantitative method.

The difference between this study and other studies is that the water quality parameters include $\mathrm{Ca}^{2+}, \mathrm{Mg}^{2+}, \mathrm{Na}^{+}, \mathrm{K}^{+}, \mathrm{Cl}^{-}$,
$\mathrm{HCO}_{3}^{-}, \mathrm{Fe}^{2+}, \mathrm{NO}_{3}, \mathrm{NO}_{2}$, and $\mathrm{SO}_{4}^{2-}$ and the research method is in line with the parameters required by the Government Regulation No. 82 of 2001. It is important to note that the data used were those collected for one season period in October 2019.

\section{Research Methods}

\subsection{Research Location}

The research location was determined purposively based on the conditions that it is the only small urbanized and inhabited island which administratively belongs to the Bandar Lampung City and that its groundwater is locally used for cooking and washing. Astronomically, Pasaran Island stretches from $5^{\circ} 27^{\prime} 43^{\prime \prime}$ to $5^{\circ} 27^{\prime} 58^{\prime \prime} S$ and $105^{\circ} 15^{\prime} 48^{\prime \prime}$ to $105^{\circ} 15^{\prime} 58^{\prime \prime} \mathrm{E}$ as indicated in Figure 1 and discovered to be the closest to Sumatra Island with a distance of only $200 \mathrm{~m}$. Its land is also reported to have grown up to the present 11 ha area a large proportion is used for cultural and artificial landscape with none for agriculture. The built-up areas including settlements and road infrastructure of the island occupy 6.29 ha of this land area while the remaining 4.13 ha is open.
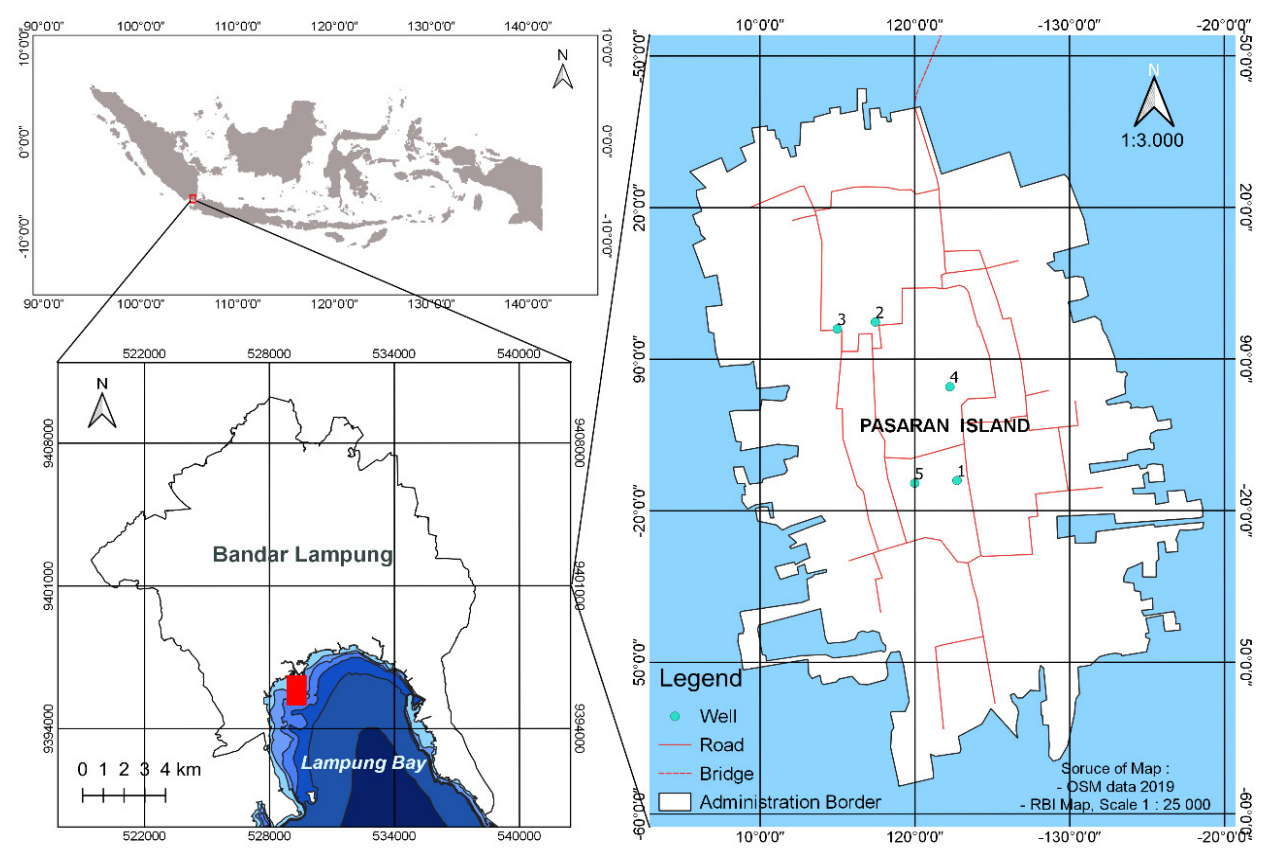

Figure 1. Pasaran Island is located north of Lampung Bay, Province of Lampung, Indonesia. 


\subsection{Research Samples}

Groundwater sampling points in the research location were selected by census and only five wells were found to be functioning properly with continuous availability of water for the local population. The points, coordinates, and description are, therefore, presented in the following Table 1.

Table 1. Coordinates of the Sampled Wells.

\begin{tabular}{|c|c|c|c|}
\hline No & $X(\mathrm{mE})$ & $\mathrm{Y}(\mathrm{mN})$ & Description \\
\hline 1 & 529350 & 93-96002 & $\begin{array}{l}\text { Mr. Kodir's well, } \mathrm{RT}^{*} 9, \\
\text { close to a fish hatchery }\end{array}$ \\
\hline 2 & 529292 & 93-96117 & $\begin{array}{l}\text { Mr. Mudri's, RT 10, close } \\
\text { to a fish hatchery }\end{array}$ \\
\hline 3 & 529265 & 93-96112 & $\begin{array}{l}\text { Mr. Sarno's, RT 10, close } \\
\text { to a fish drying area }\end{array}$ \\
\hline 4 & 529345 & 93-96070 & $\begin{array}{l}\text { Mrs. Ijah's, RT 10, close to } \\
\text { a mosque }\end{array}$ \\
\hline 5 & 529320 & 93-96000 & $\begin{array}{l}\text { Mr. Mangsu's, RT 9, close } \\
\text { to a public cemetery }\end{array}$ \\
\hline
\end{tabular}

Source: Survey Data (2019). *Neighborhood unit

\subsection{Data and Analysis}

This research was based on laboratory examination and field survey with the groundwater quality analyzed through salinity measurement and suitability analysis using clean water requirements. The salinity measurement was made with reference to Santosa's theory (2010) as indicated in Table 2 which measures Electrical Conductivity $(E C)$ as a representation or proxy of salt contents using a set of water checkers. Meanwhile, each physical, chemical, and biological groundwater element was interpreted according to the Regulation of the Minister of Health No. 32 of
2017 as presented in Table 3. The designated uses of groundwater samples were defined based on the descriptive classification of the $E C$ and the three elements according to the clean water parameters explained in Government Regulation No. 82 of 2001. Moreover, the four categories of water usage include

a) Class I water can be used as raw water for drinking and/or other purposes requiring the same water quality criteria as this designated use,

b) Class II water can be used for water recreation infrastructure/facilities, freshwater fish propagation, livestock farming, crop irrigation, and/or other purposes requiring the same water quality criteria as these designated uses,

c) Class III water can be used for freshwater fish hatchery, livestock farming, crop irrigation, and/or other purposes requiring the same water quality criteria as these designated uses,

d) Class IV water can be used for crop irrigation and/or other purposes requiring the same water quality criteria as this designated use.

Table 2. Groundwater salinity classification based on electrical conductivity.

\begin{tabular}{ccl}
\hline No & Electric conductivity () & \multicolumn{1}{c}{$\begin{array}{c}\text { Groundwater } \\
\text { salinity classes }\end{array}$} \\
\hline 1 & $<1200$ & freshwater \\
2 & $1200-2500$ & brackish water \\
3 & $2500-4500$ & saline water \\
4 & $>4500$ & brine water \\
\hline \multicolumn{3}{c}{ Source: Santosa (2010). }
\end{tabular}

Table 3. Clean water quality standards and selected parameters.

\begin{tabular}{clcccc}
\hline No & \multicolumn{1}{c}{$\begin{array}{c}\text { Elements/ } \\
\text { Compounds }\end{array}$} & Units & $\begin{array}{c}\text { Standard } \\
\text { (maximum level) }^{\mathbf{1}}\end{array}$ & $\begin{array}{c}\text { Standard } \\
\text { (maximum level) }^{\mathbf{2}}\end{array}$ & $\begin{array}{c}\text { Standard } \\
\text { (maximum level) }^{\mathbf{3}}\end{array}$ \\
\hline 1 & Taste & & Tasteless & Odorless & Tasteless \\
2 & Odor & TCU & Odorless & Tasteless & Odorless \\
3 & Color & & 15 & 50 & - \\
4 & pH & $\mathrm{mg} / 1$ & 1000 & $6.5-8.5$ & $5-9$ \\
5 & TDS & $\mathrm{mg} / 1$ & 200 & 1000 & - \\
8 & Sodium $(\mathrm{Na})$ & $\mathrm{mg} / 1$ & 400 & & - \\
11 & Sulphate $\left(\mathrm{SO}_{4}\right)$ & $\mathrm{mg} / 1$ & 250 & & - \\
12 & Chloride $(\mathrm{Cl})$ & & & - \\
\hline
\end{tabular}




\begin{tabular}{clcccc}
\hline No & $\begin{array}{c}\text { Elements/ } \\
\text { Compounds }\end{array}$ & Units & $\begin{array}{c}\text { Standard } \\
\text { (maximum level) }^{\mathbf{1}}\end{array}$ & $\begin{array}{c}\text { Standard } \\
\text { (maximum level) }^{2}\end{array}$ & $\begin{array}{c}\text { Standard } \\
\text { (maximum level) }^{3}\end{array}$ \\
\hline 13 & Nitrate $\left(\mathrm{NO}_{3}{ }^{-}\right)$ & $\mathrm{mg} / 1$ & 10 & 10 & - \\
14 & Nitrite $\left(\mathrm{NO}_{2}^{-}\right)$ & $\mathrm{mg} / 1$ & 1 & 1 & - \\
15 & Iron $(\mathrm{Fe})$ & $\mathrm{mg} / 1$ & 0.3 & 1 & - \\
16 & Total Coliform & $\mathrm{MPN} / 100 \mathrm{ml}$ & 0 & 50 & 126 \\
\hline
\end{tabular}

Source: Regulation of the Minister of Health No. 32 of 2017.

${ }^{1}$ Drinking water, ${ }^{2}$ Sanitation and hygiene: dishwashing and cooking, ${ }^{3}$ Public baths

\section{Results and Discussion}

Geological information is an essential variable in identifying groundwater sources in a region (Santosa and Adji, 2014). The Pasaran Island was, therefore, geologically found to compose of the quaternary-tertiary Lampung Formation (QTI) which was named by Van Bemmelen as the Tuff Lampung Formation (Rustadi and Gurum, 2018) because it consists of tuff, tuffaceous claystone, and tuffaceous sandstone (Mangga et al., 1993). According to Rustadi and Gurum (2018), QTI has two layers and the first is $0-15 \mathrm{~m}$ thick while the second is up to $30 \mathrm{~cm}$ thick with the groundwater in this formation existing at a depth of 3-15 $\mathrm{m}$ from the surface. It is also possible to find soil, loam, loamy sand, and tuff at a depth of 0-15 $\mathrm{m}$ and this is positively correlated with the soil texture analysis results which showed the sandy loam contains $78.88 \%$ sand, $6.81 \%$ clay, and $14.31 \%$ silt.

The geomorphological genesis of Pasaran Island occurs in several concurrent complex processes with the rivers picking up and transporting loose, weathered (eroded) materials to the river mouths through fluvial forces where sea waves and rivers meet and the materials from which non-solid sediments are formed are deposited by the dissipating energy. Moreover, the morphoassociation of the geological characters examines how past fluvial processes worked and identified similar formations in areas around the island which include the northern coastal area stretching from the west to the east. This means it is highly likely that, in addition to the influence of tidal waves, fluvial forces continually deposit volcanic materials (QTI) on the island through erosion, transportation, and sedimentation.
The geomorphological reconstruction presented in Figure $2 \mathrm{~b}$ shows that deposition starts when a barrier exists near the river mouth or when the sea wave's pressure rate (marine process) is higher than the river flow velocity. Meanwhile, the observation from the satellite images showed the coral reefs growing in a tidal zone on the west of the river mouth have created some barriers. The development of geomorphological forces over time indicates the occurrences of coastline shifts and sea-level rise and these cease the growth of coral reefs, thereby, metamorphosing them into bioclastic materials. This finding coincides with the hypothesis of Nezio et al. (2016)approximately 21,000 years B.P. that the large-scale dry conditions in the Last Glacial Period which is also referred to as the Last Glacial Maximum occurred approximately 21,000 years ago when ice sheets reached their greatest extent and contributed to a significant drop in sea levels to $120 \mathrm{~m}$ lower than the present value. Hanebuth et al. (2009) also added that the Sunda Shelf and the shallow sea between Peninsular Malaysia, Jawa, Sumatra, and Kalimantan were entirely submerged due to the sea-level rise after the Last Glacial Maximum.

The Lampung Formation found in the present time is mixed with limestones produced from the coral reel metamorphosis in the past. These coral reefs also provide evidence for the possibility of the plutonism preceding the expansion of coral reefs to the edge of igneous rocks in the seabed that created a robust shelter. Moreover, the geologic map does not record limestones but shows coral reefs beneath the mainland of Pasaran Island and extending southeastward as shown in Figure 2a based on the satellite image's interpretation results validated with the survey findings. 


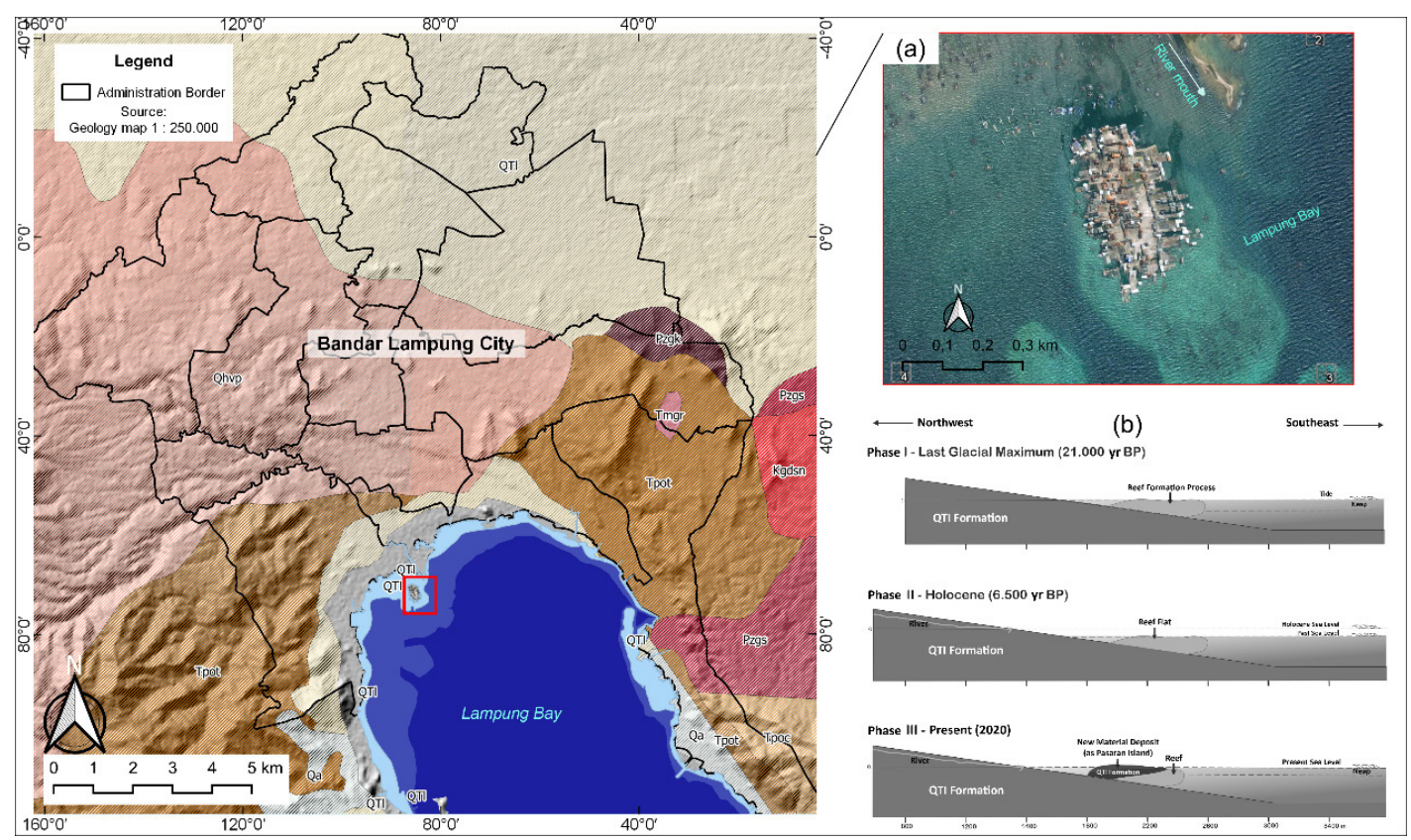

Figure 2. The Geologic Map of Pasaran Island and Its Surroundings, a) satellite image *taken from Google Earth and b) morpho-chronological sketch of its geomorphology.
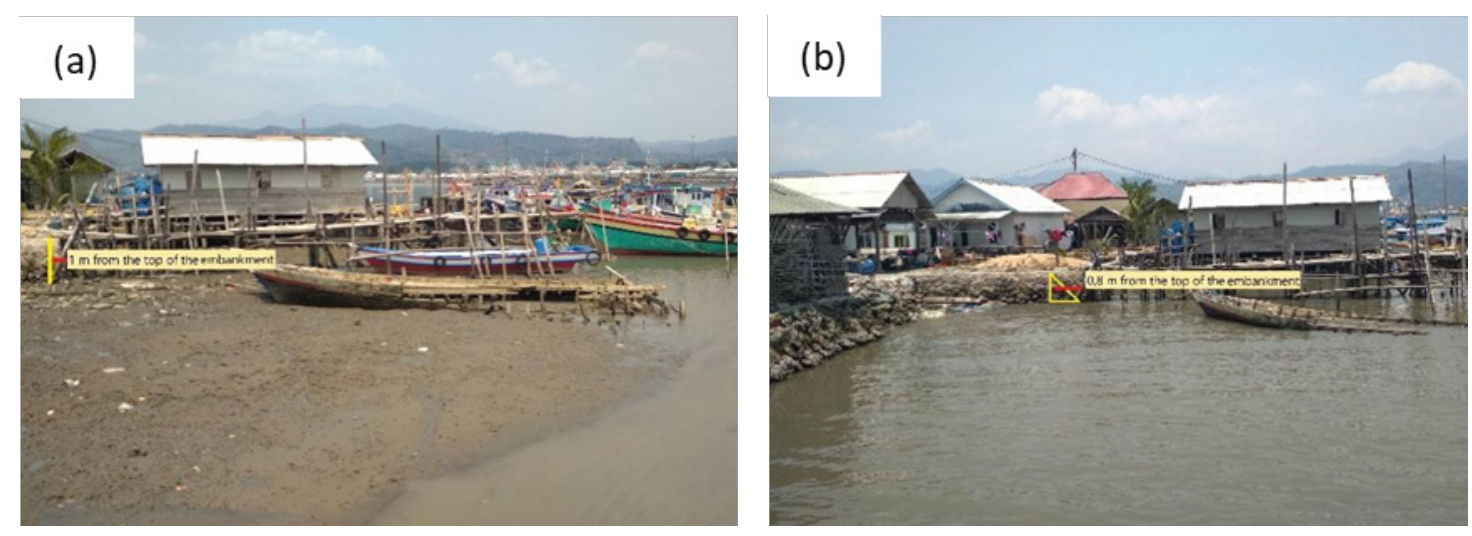

Figure 3. Tidal embankments, part of island reclamation (a) during a low tide and (b) a high tide.

This genesis shows Pasaran is a naturally occurring mixed island with grows further after reclamation. This reclamation is, in fact, observable from structures like island embankment and cementation constructed to protect natural materials from abrasion in Figure 3. Falkland et al. (1991) also explained a mixed island to be the combination of two or more islands surrounded by coral reef formation and which is composed of sediments. This geomorphological character strongly influences the stability of water quality in Pasaran Island. Meanwhile, the genesis, which depicts the origin or chronology of geomorphological processes in the past, also provides details on the mineral composition of aquifer's rock constituents which is one of the factors controlling the groundwater quality (Santosa and Adji, 2014).

\subsection{Groundwater Quality for Clean Water}

The water quality in Pasaran Island depends on the concentrations of hazardous chemicals, pollutants, and salinity levels. Therefore, the physical parameters including color and odor showed the groundwater has good quality but taste ranged from brackish to salty due to the shallow aquifer and saltwater intrusion. The temperature was also recorded to be between $24.1-25.4^{\circ} \mathrm{C}$ while the $\mathrm{pH}$ was 
between 6.9 and 7.8 but a categorically safe maximum temperature is $25^{\circ} \mathrm{C}$ (Cunliffe et al., 2011). Meanwhile, the chemical parameters including $\mathrm{Ca}^{2+}, \mathrm{Mg}^{2+}, \mathrm{Na}^{+}, \mathrm{K}^{+}, \mathrm{Cl}^{-}, \mathrm{HCO}_{3}^{-}$, $\mathrm{Fe}^{2+}, \mathrm{NO}_{3}, \mathrm{NO}_{2}$, and $\mathrm{SO}_{4}^{2}$, and showed Wells no. $1,2,4$, and 5 contained high chloride $\left(\mathrm{Cl}^{-}\right)$ and sodium $\left(\mathrm{Na}^{2+}\right)$ levels which exceed the maximum allowable in potable water but were within the standards for sanitation, hygiene, and public baths. Chloride was spatially found at a relatively low concentration in the middle of the island which is Well no. 3 and later increased with distance towards the southeastern and northeastern outer zones. This distribution indicates the intrusion of the groundwater interface zone in the research location due to the sea waves coming from the southeast-northwest in line with the previous findings that the presence of higher chlorides indicates a larger effect of seawater intrusion (Cahyadi, 2015). Meanwhile, the sulfate $\left(\mathrm{SO}_{4}{ }^{2-}\right.$ ) , nitrite $\left(\mathrm{NO}_{2}\right)$, and iron $\left(\mathrm{Fe}^{2+}\right)$ contents were within the safe limits for clean water supplies as indicated in Table 4.

The chemical pollutant $\mathrm{NO}_{3}$ which is hazardous to human health was detected in Wells no. 1, 4, and 5 at concentrations exceeding its maximum allowable in drinking water (10.00) as well as sanitation and hygiene (50.00) but were safe for public baths. It is possible for the pollutants to increase basically due to the lack of water management process and rapid growth of human activities (Purnama and Cahyadi, 2019). Moreover, high $\mathrm{NO}_{3}$ contents are also thought to be caused by the absence of a communal wastewater treatment plant (WWTP) to manage the sanitation system in a narrow area like Pasaran Island. This led to the intensification of waste concentration and distribution in the soil and potentially permeates the groundwater systems when rainwater infiltrates the ground and comes into contact with subsurface materials. It is also attributable to non-uniform denitrification which reduces nitrate to gaseous nitrogen or nitrite (Lerner, 2005).

The groundwater's biological quality was found to have consisted of $170 \mathrm{MPN} / 100 \mathrm{ml}$ of total coliform with the lowest concentration recorded to be $6.8 \mathrm{MPN} / 100 \mathrm{ml}$ as indicated in Figure 4. Total coliform is a commonly used indicator of biological contaminants in groundwater (WHO-UNICEF, 2012; Cunliffe et al., 2018) which determines the safety of a water resource for consumption due to its ability to cause harm to the human body. It was, however, generally discovered that domestic activities are responsible for groundwater's biological pollutants because most of the island is dominated by settlements. The use of the surrounding environment as a waste disposal site exacerbates the pollution due to the ability of the wastewater to seep into infiltration wells and cause pollution in groundwater layers (Maryono, 2016). The total coliform and clean water requirements showed that Well no. 1 has poor quality while Wells no. 2 to 5 are safe for any purposes requiring clean water.

Table 4. Parameter analysis of five groundwater samples in Pasaran Island.

\begin{tabular}{|c|c|c|c|c|c|c|c|c|c|c|}
\hline \multirow[b]{2}{*}{ No } & \multirow[b]{2}{*}{ Elements } & \multirow[b]{2}{*}{ Units } & \multirow[b]{2}{*}{ Well 1} & \multirow{2}{*}{$\begin{array}{c}\text { Well } \\
2\end{array}$} & \multirow{2}{*}{$\begin{array}{c}\text { Well } \\
3\end{array}$} & \multirow{2}{*}{$\begin{array}{c}\text { Well } \\
4\end{array}$} & \multirow{2}{*}{$\begin{array}{c}\text { Well } \\
5\end{array}$} & \multicolumn{3}{|c|}{ Standard (maximum level)* } \\
\hline & & & & & & & & Drinking & $\begin{array}{l}\text { Sanitation- } \\
\text { hygiene }\end{array}$ & $\begin{array}{l}\text { Public } \\
\text { baths }\end{array}$ \\
\hline 1 & Sodium () & $\mathrm{mg} / 1$ & 741 & 852 & 179 & 915 & 925 & 200 & - & - \\
\hline 2 & Sulfate () & $\mathrm{mg} / 1$ & 272 & 197 & 146 & 249 & 276 & 400 & 400 & - \\
\hline 3 & Chloride () & $\mathrm{mg} / 1$ & 3374.8 & 2779.3 & 79.9 & 3771.9 & 3474.1 & 250 & - & - \\
\hline 4 & Nitrate & $\mathrm{mg} / 1$ & 98.09 & 8.85 & 31.7 & 65.49 & 141.52 & 10 & 50 & - \\
\hline 5 & Nitrite & $\mathrm{mg} / 1$ & 0.031 & 0.312 & 0.051 & 0.051 & 2.92 & 1 & 3 & - \\
\hline 6 & Iron () & $\mathrm{mg} / \mathrm{l}$ & $<0.01$ & $<0.01$ & $<0.01$ & $<0.01$ & $<0.01$ & 0.3 & 1 & - \\
\hline 7 & $\begin{array}{c}\text { Total } \\
\text { Coliform }\end{array}$ & $\mathrm{MPN} / 10 \mathrm{ml}$ & 170 & 33 & 33 & 6.8 & 130 & 0 & 50 & 126 \\
\hline
\end{tabular}

Source: Laboratory test (2019), ${ }^{*}$ standards are based on the Regulation of the Minister of Health No. 32 of 2007 


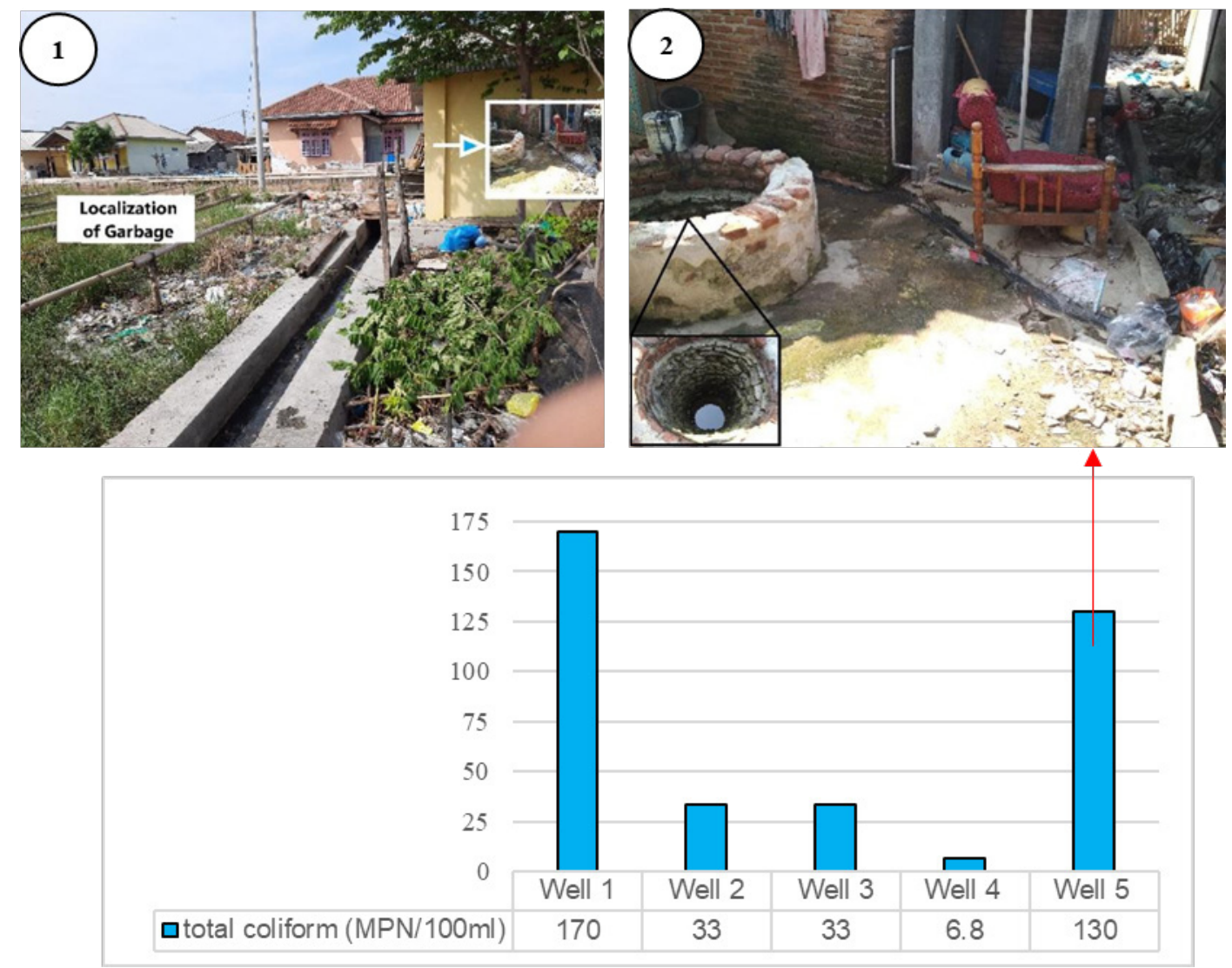

Figure 4. Total coliform of groundwater samples collected from Pasaran Island.

The results showed most clean water quality parameters including physical, chemical, and biological in the research location exceeded the upper thresholds. Table 5 presents the classification of groundwater suitability for clean water and the groundwater quality in Pasaran Island was found to be good and can, therefore, be supplied for clean water for domestic needs. Well no. 1 was, however, found not to be suitable for sanitation and hygiene as well as public baths while the other four wells can be safely utilized for public baths while only Wells no. 2 and 3 are good for sanitation hygiene purposes such as dish and cloth washing. Meanwhile, the groundwater quality is considered poor based on the Regulation of the Minister of Health No. 32 of 2007 and classified as suitable for Class II-water purposes based on the Government Regulation No. 82 of 2001. These results are expected to provide the information required by the local people on the groundwater conditions in their homes, thereby, allowing them to anticipate different probable adverse impacts earlier. It also provides them and the government the inputs and considerations in promoting proper management strategies.

There are internal and external factors causing low water quality with the internal ones observed to be including unregulated household waste disposal systems especially for plastic waste and sparse vegetation while the external ones are the threats of high waves and contaminations from seawater with often inundates the island and indirectly cause a decline in the quality and availability of safe groundwater. Schneider and Kruse (2005) found that excessive water extraction potentially triggers groundwater degradation due to its ability to reduce the lens thickness and supply. 
Table 5. Groundwater suitability for clean water in Pasaran island.

\begin{tabular}{ccccc}
\hline No & Samples & Drinking/consumption & Sanitation and hygiene & Public baths \\
\hline 1 & Well 1 & $\times$ & $\times$ & $\times$ \\
2 & Well 2 & $\times$ & $\checkmark$ & $\checkmark$ \\
3 & Well 3 & $\times$ & $\checkmark$ & $\checkmark$ \\
4 & Well 4 & $\times$ & $\times$ & $\checkmark$ \\
5 & Well 5 & $\times$ & $\times$ & $\checkmark$ \\
\hline
\end{tabular}

Source: Data analysis (2020)

Notes: $\times:$ not safe for this purpose

$\checkmark$ : safe for this purpose

Table 5 shows Pasaran Island has Class IIwater quality and this means the groundwater properties have exceeded their respective maximum recommended values, notably for drinking and sanitation-hygiene purposes. Moreover, in terms of salinity, the EC measured was relatively high at $3900 \mu \mathrm{S} / \mathrm{cm}$ and Bailey et al. (2010) argued that rainfall and shoreline retreat caused by wave actions are responsible for the change in the salinity of groundwater inside a well. This is also in line with the findings of Mensah and FitzGibbon (2013) that frequent and intense tidal inundation has the ability to degrade groundwater quality, thereby, allowing less control over salinity levels while a decrease in its occurrences can slowly improve the quality and this process is known as "overtopping and flood reduction". However, Cahyadi (2015) explained that groundwater quality decline in small islands is often attributable to limestone composition in regional geology and domestic wastes. This situation has the ability to leads to clean water scarcity in Pasaran Island when appropriate treatment strategies are not implemented. This is in line with the assumption of Widada et al. (2017) that water resource availability is increasingly limited and even scarce mostly due to the environmental degradation and water quality decline caused by pollution.

\section{Conclusion}

Pasaran is geologically and geomorphologically a mixed island composed of tuffs underlying the materials from metamorphosed coral reefs while the sands from reclamation are on the surface, thereby, contributing to high permeability. This further indicates a high possibility of salt water and fresh water mixing due to seawater intrusion and this has the potential to affect the stability of the water quality on the island.

The groundwater was discovered to have low quality due to the presence of chloride $\left(\mathrm{Cl}^{-}\right)$, sodium $\left(\mathrm{Na}^{+}\right)$, nitrate $\left(\mathrm{NO}_{3}\right)$, and total coliform which exceed the maximum recommended values for drinking water and sanitation-hygiene purposes.

\section{Acknowledgment}

This article is part of the master's thesis required to complete the Postgraduate Study Program of the Faculty of Geography, Universitas Gadjah Mada. The authors appreciate all the parties involved in its completion for their support especially the residents of Pasaran Island for their participation as well as the reviewers for their invaluable suggestions to improve the manuscript. 


\section{References}

Bailey, R. T, Jenson, J. W., and Olsen, A. E. (2010). Estimating the Ground Water Resources of Atoll Islands. Water. Vol. 2, No. 1, pp. 1-27.

Bailey, R. T., Barnes, K., and Corey D. W. (2016). Predicting Future Groundwater Resources of Coral Atoll Islands. Hydrological Processes. Vol. 30, No. 13, pp. 2092-2105.

Cahyadi, A. (2015). Analisis Potensi Sumberdaya Air Pulau Koral Sangat Kecil (Studi Kasus di Pulau Koral Pramuka, Kepulauan Seribu, DKI Jakarta) [Analysis of Water Resource Potential on Very Small Coral Islands (Case Study: the Pramuka Coral Island, Seribu Island, the Greater Region of Jakarta]. Master Tesis. Yogyakarta: Fakultas Geografi, Universitas Gadjah Mada.

Cunliffe, D., Bartram, J., Briand, E., Chartier, Y., Colbourne, J., Drury, D., Lee, J., Schaefer, B., and SurmanLee, S. (2011). Water Safety in Buildings. Switzerland: World Health Organization.

Cunliffe, D., Fawell, J., and Jackson, D. (2018). Developing Drinking-Water Quality Regulations and Standards (General Guidance with a Special Focus on Countries with Limited Resources). Switzerland: World Health Organization.

Falkland, A. C., Custodio, E., Arenas, A. D., and Simler, L. (1991). Hydrology and Water Resources of Small Islands : A Practical Guide. France: United Nations Educational, Scientific and Cultural Organization.

Hanebuth, T. J. J., Stattegger, K., and Bojanowski, A. (2009). Termination of the Last Glacial Maximum Sea-Level Lowstand The Sunda-Shelf. Global and Planetary Change. Vol. 66, No. 1-2, pp. 76-84.

Lerner, D. N. (2005). Urban Groundwater Pollution. Netherlands: A.A. Belkema.

Mangga, S. A., Amiruddin., Suwarti, T., Gafoer, S., and Sidarto. (1993). Systematic Geological Map of Indonesia, Quadrangle of Tanjung Karang, Scale 1: 250.000. Jakarta: Geological Research and Development Centre.

Mensah, K. O., and FitzGibbon, J. (2013). Responsiveness of Ada Sea Defence Project to Salt Water Intrusion Associated with Sea Level Rise. Journal of Coastal Conservation. Vol. 17, No. 1, pp. 75-84.

Nezio, P. N D., Timmerman, A., Tierney, J. E., Jin, F., Otto-bliesner, B., Rosenbloom, N., Mapes, B., Neale, R., Ivanovic, R. F., and Montenegro, A. (2016). The Climate Response of the IndoPacific Warm Pool to Glacial Sea Level. Paleoceanography. Vol. 31, No. 1, pp. 866-894.

Nunn, P. D. (1986). Small Island and Geomorphology: Review and Prospect in the Context of Historical Geomorphology. The Royal Geographical Society. Vol. 12, No. 2, pp. 227-239.

Peraturan Menteri Kesehatan Nomor 32 Tahun 2017 tentang Standar Baku Mutu Kesehatan Lingkungan dan Persyaratan Kesehatan Air untuk Keperluan Higiene Sanitasi, Kolam Renang, Solus Per Aqua, dan Pemandian Umum [Regulation of Minister of Health No. 32 of 2007 on Environmental Health Quality Standards and Water Health Requirements for Sanitation-Hygiene Purposes, Swimming Pools, Solus Per Aqua, and Public Baths]. Jakarta: Minister of Health of the Republic of Indonesia.

Peraturan Pemerintah Nomor 82 Tahun 2001 tentang Pengelolaan Kualitas Air dan Pengendalian Pencemaran Air [Governmental Regulation No. 82 of 2001 on Water Quality Management and Water Pollution Control]. Jakarta: Government of the Republic of Indonesia. 
Purnama, S. (2010). Hidrologi Airtanah [Groundwater Hydrology]. Yogyakarta: Kanisius.

Purnama, S., and Cahyadi, A. (2019). Groundwater Vulnerability to Pollution in Kasihan District, Bantul Regency, Indonesia. Forum Geografi. Vol. 33 (December), pp. 140-152.

Rustadi, and Gurum, A. P. (2018). Pencitraan Geolistrik untuk Eksplorasi Airtanah di Ambarawa, Lampung [Geoelectric Imaging for Groundwater Exploration in Ambarawa, Lampung]. Publikasi LPPM UNILA. Vol. 1, No. 1, pp. 1-6.

Santosa, L. W. (2010). Kajian Genesis Bentuklahan dan Pengaruhnya terhadap Hidrostratigrafi Akuifer dan Hidrokimia sebagai Geoindikator Evolusi Airtanah Bebas Pada Bentanglahan Kuarter Kabupaten Kulonprogo Bagian Selatan, Daerah Istimewa Yogyakarta [Study of Landform Genesis and Its Effects on Aquifer Hydrostratigraphy and Hydrochemicals as Geoindicators of Unconfined Groundwater Evolution in the Quaternary Landscape in Southern Kulonprogo Regency, the Special Region of Yogyakarta]. Dissertation. Faculty of Geography, Universitas Gadjah Mada.

Santosa, L. W., and Adji, T. N. (2014). Karakteristik Akuifer dan Potensi Airtanah Graben Bantul [Aquifer Characteristics and Groundwater Potential in the Graben Bantul]. First Edition. Yogyakarta: Gadjah Mada University Press.

Schneider, J. C., and Kruse, S. E. (2005). Assessing Selected Natural and Anthropogenic Impacts on Freshwater Lens Morphology on Small Barrier Islands: Dog Island and St. George Island, Florida, USA. Hydrogeology Journal. Vol. 14, No. 1-2, pp. 131-145.

Sudarmadji., Hadi, P., and Widyastuti, M. (2019). Pengelolaan Sumberdaya Air Terpadu [Integrated Water Resource Management]. Third Edition. Yogyakarta: Gadjah Mada University Press.

UNESCO-IHP and UNEP. (2016). Transboundary Aquifers and Groundwater Systems of Small Island Developing States: Status and Trends, Summary for Policy Makers. Kenya

White, I., Falkland, T., and Perez, P. (2004). Sustainable Development of Water Resources in Small Island Nations of the Pacific. Proceeding in Asia Pacific Association of Hydrology and Water Resources Conference, Singapore: Asia Pacific Association of Hydrology and Water Resources. Vol. 2, pp. 345-356.

WHO-UNICEF. (2012). Rapid Assessment of Drinking Water Quality - A Handbook for Implementation. Switzerland: World Health Organization.

Widada, S., Satriadi, A., and Rochaddi, B. (2017). Kajian Potensi Airtanah Berdasarkan Data Geolistrik Resistiviti untuk Antisipasi Kekeringan di Wilayah Pesisir Kangkung, Kabupaten Kendal, Privinsi Jawa Tengah [Groundwater Potential Study Based on Geoelectrical Resistivity Data as Drought Anticipation in the Kangkung Coastal Area, Kendal Regency, Province of Jawa Tengah]. Jurnal Kelautan Tropis. Vol. 20, No. 1, pp. 35-41. 